Edward Bahou, MD

Lan Zhou, MD, PhD

Neurol Neuroimmunol

Neuroinflamm

2017;4:e365; doi: 10.1212

NXI.0000000000000365

\section{ANCA-ASSOCIATED VASCULITIS PREDOMINANTLY PRESENTING WITH SEVERE MYALGIAS \\ OPEN}

The peripheral nervous system is frequently involved in anti-neutrophil cytoplasmic antibody (ANCA)associated vasculitis (AAV), with typical presentations such as mononeuritis multiplex, distal sensorimotor polyneuropathy, and isolated cranial mononeuropathies. ${ }^{1,2}$ Here, we report a case of AAV with unusual presentation of predominant severe myalgias. The diagnosis of AAV was made by a muscle biopsy and positive ANCA.

Case report. A 63-year-old woman developed rapid onset of soreness in the muscles of buttocks and thighs. Over the course of 3 weeks, the symptoms involved her upper arms. Climbing stairs and washing her hair became difficult because of the pain. She denied spine pain or numbness. She denied fever, weight change, appetite loss, joint pain, skin rash, or urinary symptoms. She had a history of hypothyroidism, and had mild left foot weakness as a result of poliomyelitis infection when she was 3 years old. She did not smoke cigarettes or drink alcohol.

She was admitted to an outside hospital, where thyroid-stimulating hormone, antinuclear antibody, extractable nuclear antigen, and rheumatoid factor were found to be unremarkable. Cervical and lumbosacral spine MRI with and without contrast showed mild multi-level degenerative changes. She was discharged without a clear diagnosis. One week later, she presented to our emergency room for the progressive symptoms that significantly affected her function. She could only walk half a city block and could not function as a podiatrist because of the severe pain and fatigue in the proximal limb muscles. She was admitted to our neurology service for the management.

Physical examination showed normal mental status, cranial nerve function, sensation, and coordination. There was severe tenderness to palpation of the bilateral deltoid and biceps muscles. Strength was intact except for the known mild residual weakness in the left foot and toes from her prior polio infection. Deep tendon reflexes were $2+$ except for the absent ankle jerks. On her gait examination, she
Clinical/Scientific Notes

favored her right side and fatigued very quickly, requiring frequent rest.

Laboratory testing revealed mildly elevated creatinine phosphokinase level of 367 IU/L (normal 25-175) and aldolase of 9.1 U/L (normal 1.5-8.1). C-reactive protein (CRP) and erythrocyte sedimentation rate (ESR) were markedly elevated at $124 \mathrm{mg} / \mathrm{L}$ (normal 0-5.0) and $79 \mathrm{~mm} / \mathrm{h}$ (normal 0-20), respectively. ANCA titer was elevated at 1:160 (normal $<1: 20$ ), and myeloperoxidase antibody was positive at $186 \mathrm{U} / \mathrm{mL}$ (normal 0-19). Antibodies to proteinase 3 and Jo-1 were negative. Urinalysis showed microscopic hematuria and proteinuria. Chest CT showed a very small lung nodule. Nerve conduction study was normal. EMG showed no abnormal spontaneous activity but subtle early recruitment of a few small motor unit potentials in the biceps and deltoid muscles, suggestive of a nonirritable myopathy. A left deltoid muscle biopsy showed acute necrotizing vasculitis with transmural inflammation and fibrinoid necrosis of several small- and medium-sized perimysial blood vessels (figure). No myopathic changes or endomysial inflammation was seen. She was diagnosed with AAV, and treated with IV infusion of methylprednisolone $1 \mathrm{~g} / \mathrm{d}$ for 5 days with dramatic improvement of her symptoms. Subsequent renal biopsy showed crescentic glomerulonephritis. She was discharged on oral prednisone and started on rituximab by rheumatology.

Discussion. ANCA are autoantibodies to neutrophilic granules and monocytic lysosomes. ANCA have been associated with 3 distinct vasculitides, which involve inflammation of the small- and medium-sized blood vessels: microscopic polyangiitis (MPA), granulomatosis with polyangiitis (GPA, previously known as Wegener granulomatosis), and eosinophilic GPA (previously known as Churg-Strauss Syndrome). ${ }^{3,4}$ Our case represents MPA.

The estimated prevalence of AAV is 46-184 per million. ${ }^{5}$ AAV is a multisystem disease. Nervous system is frequently involved in AAV with peripheral neuropathy predominated in each type of AAV. ${ }^{1}$ Patients with MPA are usually older with more severe renal disease along with skin rash and neuropathy. ${ }^{4}$ Although myalgias are not uncommon in AAV, 

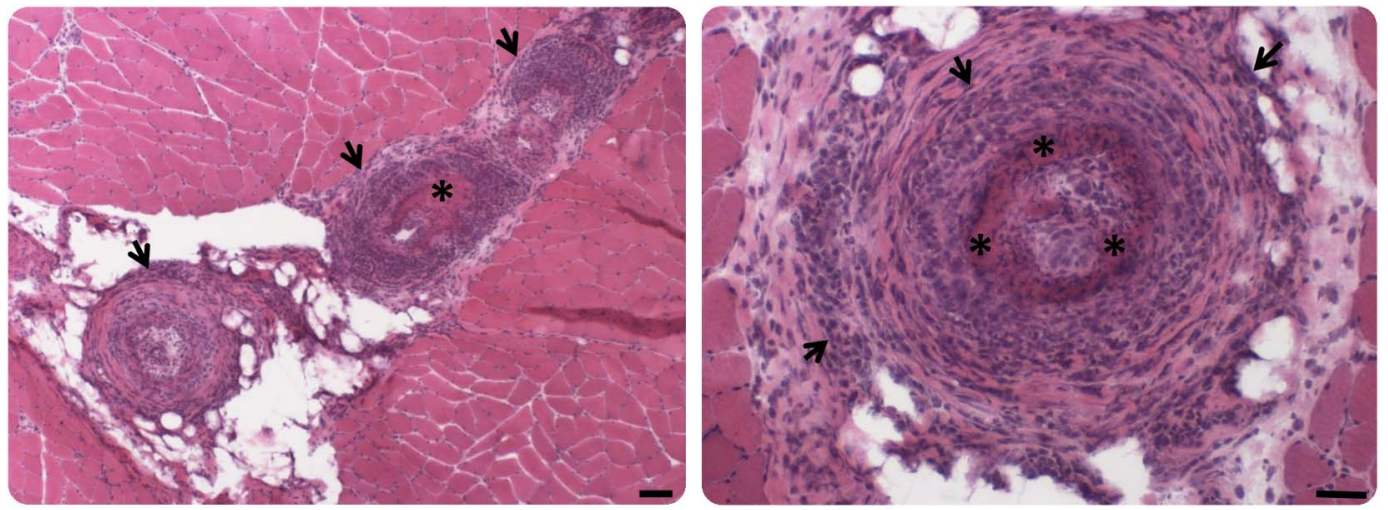

H\&E stain showed transmural inflammation (arrows) and fibrinoid necrosis (stars) of several perimysial blood vessels with severe occlusions of blood vessel lumen. Bar $=50 \mu \mathrm{m}$.

which have been reported in $48.2 \%$ patients with MPA, ${ }^{6}$ myalgias as a predominant presentation without other systemic symptoms or neuropathies typical of AAV is exceedingly rare. The clinical diagnosis can be delayed as seen in our case because of this rare entity. Our patient did not have objective weakness and the EMG findings were very subtle, but the muscle biopsy showed fulminant necrotizing vasculitis. The severe myalgias are most likely due to muscle ischemia. Our patient responded very well to the treatment. Our case illustrates that acute, severe, and progressive myalgias should raise a suspicion for vasculitis, especially in a setting of markedly elevated ESR and CRP, and positive ANCA. Biopsy of a symptomatic muscle is essential to establish a tissue diagnosis to initiate prompt treatment.

Department of Neurology, Icahn School of Medicine at Mount Sinai, New York, NY.

Author contributions: Dr. Bahou and Dr. Zhou participated in the management of the patient; did chart review and data analysis; and drafted the manuscript. Dr. Zhou interpreted the muscle biopsy.

Study funding: No targeted funding reported.

Disclosure: Dr. Bahou reports no disclosures. Dr. Zhou is an Associate Editor for Neurology ${ }^{\circledR}$ Neuroimmunology \& Neuroinflammation. Go to Neurology.org/nn for full disclosure forms. The Article Processing Charge was funded by the authors.
This is an open access article distributed under the terms of the Creative Commons Attribution-NonCommercial-NoDerivatives License 4.0 (CC BY-NC-ND), which permits downloading and sharing the work provided it is properly cited. The work cannot be changed in any way or used commercially without permission from the journal.

Received January 24, 2017. Accepted in final form April 17, 2017.

Correspondence to Dr Zhou: lan.zhou@mssm.edu.

1. Zhang W, Zhou G, Shi Q, Zhang X, Zeng XF, Zhang FC. Clinical analysis of nervous system involvement in ANCAassociated systemic vasculitides. Clin Exp Rheumatol 2009; 27:S65-S69.

2. Koike H, Sobue G. Clinicopathological features of neuropathy in anti-neutrophil cytoplasmic antibody-associated vasculitis. Clin Exp Nephrol 2013;17:683-685.

3. Kallenberg CG. The diagnosis and classification of microscopic polyangiitis. J Autoimmun 2014;48-49:90-93.

4. Yates M, Watts R. ANCA-associated vasculitis. Clin Med (Lond) 2017;17:60-64.

5. Watts RA, Mahr A, Mohammad AJ, Gatenby P, Basu N, Flores-Suarez LF. Classification, epidemiology and clinical subgrouping of antineutrophil cytoplasmic antibody (ANCA)-associated vasculitis. Nephrol Dial Transpl 2015;30 (suppl 1):i14-i22.

6. Guillevin L, Durand-Gasselin B, Cevallos R, et al. Microscopic polyangiitis: clinical and laboratory findings in eighty-five patients. Arthritis Rheum 1999;42:421-430. 


\section{Neurology \\ Neuroimmunology \& Neuroinflammation}

\section{ANCA-associated vasculitis predominantly presenting with severe myalgias}

Edward Bahou and Lan Zhou

Neurol Neuroimmunol Neuroinflamm 2017;4;

DOI 10.1212/NXI.0000000000000365

This information is current as of June 16, 2017

Updated Information \& Services

References

Subspecialty Collections

Permissions \& Licensing

Reprints including high resolution figures, can be found at:

http://nn.neurology.org/content/4/4/e365.full.html

This article cites 6 articles, 0 of which you can access for free at: http://nn.neurology.org/content/4/4/e365.full.html\#\#ref-list-1

This article, along with others on similar topics, appears in the following collection(s):

Muscle disease

http://nn.neurology.org//cgi/collection/muscle_disease

Vasculitis

http://nn.neurology.org//cgi/collection/vasculitis

Information about reproducing this article in parts (figures,tables) or in its entirety can be found online at:

http://nn.neurology.org/misc/about.xhtml\#permissions

Information about ordering reprints can be found online:

http://nn.neurology.org/misc/addir.xhtml\#reprintsus

Neurol Neuroimmunol Neuroinflamm is an official journal of the American Academy of Neurology.

Published since April 2014, it is an open-access, online-only, continuous publication journal. Copyright

Copyright (C) 2017 The Author(s). Published by Wolters Kluwer Health, Inc. on behalf of the American

Academy of Neurology.. All rights reserved. Online ISSN: 2332-7812.

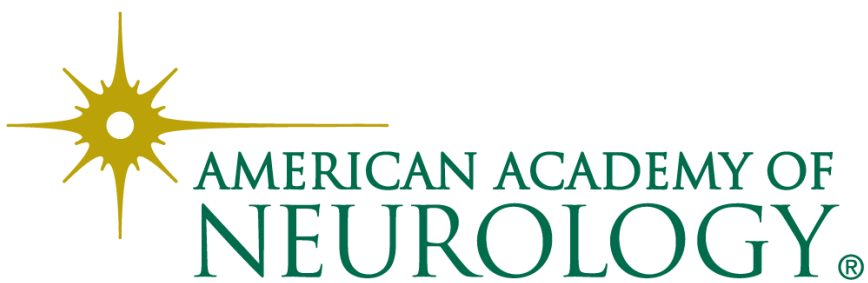

